\title{
KEDUDUKAN ANAK DALAM ALQURAN (Suatu Pendekatan Pendidikan Islam)
}

\author{
Sulaiman Saat \\ Fakultas Tarbiyah dan Keguruan UIN Alauddin Makassar \\ Email: sulaimansaat0655@gmail.com
}

\begin{abstract}
This paper departs from the main problem of how the position of children according to the concept of the Qur'an by making an approach from the eyes of Islamic education. The Qur'an is a timeless guide in every human activity, including education. The Qur'an has given clues about children's education. Children are the most important asset, capital, investment of every family that must be maintained, nurtured, cared for, educated. The Qur'an has given guidance to it. In the Qur'an many verses are found related to education, both the purpose, method, and the content of education itself.
\end{abstract}

Keywords: position, child, Qur'an, approach, education, and Islam.

\section{PENDAHULUAN}

\section{A. Latar Belakang Masalah}

$\mathrm{P}$ endidikan Anak merupakan masalah yang amat penting untuk dilaksanakan dengan sebaik-baiknya. Hal ini disebabkan karena anak menduduki posisi yang sangat penting dalam kehidupan, baik dalam keluarga maupun dalam kehidupan masyarakat. Anak merupakan generasi pelanjut dari satu generasi. Alquran sendiri memberikan kedudukan yang amat penting dalam kehidupan anak dengan berbagai istilah yang digunakan. Mislanya dalam surah Al-Kahfi disebutkan anak sebagai perhiasan dalam kehidupan dunia. Allah berfirman: "harta dan anak-anak adalah perhiasan dalam kehidupan dunia..." (QS. Al Kahfi/18: 46). Dalam QS. Ali Imran/3: 14, Allah SWT. berfirman: "Dijadikan indah pada (pandangan) manusia kecintaan kepada apa-apa yang diingini, yaitu wanita-wanita, anak-anak, harta yang banyak dari emas, perak, kuda pilihan, binatang-binatang ternak sawah, ladang. Itulah kesenangan hidup di dunia dan di sisi Allahlah tempat kembali yang baik (surga). ${ }^{2}$.Kedua ayat tersebut, dan masih banyak ayat yang lain, memberikan gambaran betapa pentingnya kedudukan anak. Anak-anak digambarkan sebagai perhiasan, yakni sesuatu yang sangat berharga sehingga membutuhkan perlindungan dan pemeliharaan yang sungguhsungguh. Salain itu, anak-anak merupakan objek kecintaan seseorang. Sebagai barang yang sangat dicintai, anak sangat membutuhkan perhatian untuk dilindungi, diayoni, dikembangkan, diarahkan dan sebagainya. Anak disamakan dengan harta kekayaan

\footnotetext{
${ }^{1}$ Departemen Agama RI, Al-Quran dan Terjemahnya, (Saudi Arabiah: Mujamma' Al Malik Fahd Li Tiba'at Mush-haf Asy-Syarif Medinah Almunawwarah, t.th), h. 450.

${ }^{2}$ Ibid., h. 77.
} 
seperti emas, perak, sawah ladang, dan sebagainya. Hal ini menunjukkan betapa pentingnya dan berharganya seorang anak dalam sebuah keluarga. Kehadiran seorang anak dalam keluarga merupakan suatu kebahagiaan tersendiri, dan memunculkan berbagai perasaan-psikologis. Abdullah Nashih Ulwan mengatakan, bahwa dalam hati orang tua akan tumbuh perasaan cinta terhadap anak dan tumbuh pula perasaanperasaan psikologis lainnya, berupa perasaan kebapakan dan keibuan untuk memelihara, mengasihi,, menyayangi dan memperhatikan anak. ${ }^{3}$

Begitu berharganya kehadiran anak dalam pandangan Allah swt. yang disamakan dengan perhiasan, dianggap sebagai penyejuk hati, di suatu sisi, namun di lain sisi ditemukan dalam kehidupan masyarakat banyak yang seakan tidak menghargai sedikitpun kehadiran seorang anak. Di media-media ditemukan ada orang tua yang membunuh anaknya tiga orang dengan jalan meracuni, hanya karena takut masa depan anaknya yang tidak jelas karena ditinggalkan oleh suaminya, ada orang tua membuang bayinya di drainase, ada yang mebunuh dengan jalan aborsi dan sebagainya.

Hal ini menunjukkan betapa pentingnya hal ini dipahami oleh masyarakat, tanpa membedakan agama, kepercayaan, suku, atau kelompok masyarakat tertentu, karena kehadiran anak dan perlindungan terhadap anak, termasuk pembinaan dan pendidikan bagi anak-anak merupakan amanah yang diletakkan Allah Swt. di pundak seluruh umat manusia. Oleh karena itu hal ini menjadi hal yang sangat penting untuk didiskusikan dalam program Pascasarna dengan pendekatan tafsir Maudu'I, agar hal ini menjadi terang dan komprehensif, tidak bersifat parsial, tetapi didekati secara komprehensif dari satu sudut pandang tertentu.

\section{B. Rumusan Masalah}

Berdasarkan latar belakanga masalah tersebut, maka masalah pokok yang akan dibahas dalam makalah ini, adalah "bagaimana pendidikan anak menurut Alquran (suatu pendekatan tafsir maudu'i?"

Bertolak dari pokok permasalahan tersebut, dapat dirumuskan beberapa sub masalah sebagai berikut:

1. Bagaimana pandangan Alquran tentang Anak?

2. Bagaimana metode mendidik anak menurut Alquran ?

3. Apa yang isi pendidikan anak menurut Alquran?

\section{PEMBAHASAN.}

\section{A. Anak dalam Pandangan Alquran}

Sebelum membahas tentang pendidikan, terlebih dahulu dikemukakan pengertian anak dalam Alquran. Dalam Alquran, ada beberapa kata yang dapat diartikan anak, yaitu kata 'al-ibn', dan 'al-walad'. Kata al-ibn menurut Ibn Sayyidih Mutsannanya

3 Abdullah Nashih Ulwan, Tariyah al-aulad fi al-Islam, Diterjemahkan oleh Jamaluddin Miri dengan judul "Pendidikan Anak Dalam Islam", (Jakarta: Pustaka Amani, 2007), h. 27. 
adalah ibnatun dan bintun, yang menurut Abu Hanifah, kata yang terakhir asalnya adalah banuta dan wazannya faala. Namun huruf ta pada kata bintun bukanlah tanda muannas. ${ }^{4}$ Adapun kata walad yang terdiri dati huruf al-wauw, al-lam, dan al-dal yang kesemuanya adalah huruf shahih, yang berarti petunjuk tentang kelahiran, kemudian diqiyaskan kepada yang lainnya, seperti (anak) atau al-walad yang dipakai untuk menunjukkan pada yang satu maupun semuanya. Kata ini mengandung makna sesuatu itu lahir dari sesuatu atau dapat juga diartikan terjadi dari padanya. ${ }^{5}$

Dalam kamus Krafyak al-Ashrin disebutkan bahwa kata waladun dari kata kerja walladah, bisa berarti ahdatsa(menciptakan), an-tajah (memperoduksi), kawwanah (membentuk), sabbaba (menyebabkan), juga bisa berarti rabb (mendidik). ${ }^{6}$

Pengertian-pengertian tersebut di atas, dapat dipahami bahwa kata anak yang terambil dari kata bintun, banaat, berarti anak atau keturunan berdasarkan biologis. Misalnya si pulan adalah anak atau keturunan dari si pulan. Sedangkan anak yang terambil dari kata walada, juuladu dapat berarti memperoduksi, membentuk, menyebabkan, atau menciptakan. Misalnya sebuah lembaga memproduksi/ melahirkan sarjana.

Dalam Undang-Undang Nomor 23 tahun 2002 tentang Perlindungan Anak, pada Bab 1 pasala 1 ayat 1 menyatakan bahwa Anak adalah seseorang yang belum berusia 18 (delapan belas) tahun, termasuk anak yang dalam kandungan. ${ }^{7}$ Pendidikan yang umum digunakan, berkaitan dengan tiga istilah yang umum digunakan dalam pendidikan Islam, yaitu 'al-Tarbiyah, al Ta'lim, dan al Ta'dib'. Baik 'al-Tarbiyah, alta'lim maupun al-ta'dib', merujuk kepada Allah. Tarbiyah dipahami sebagai kata bentukan dari kara "rabb" atau "rabba" yang mengacu kepada Allah sebagai 'rabb alālamin', yang mengandung makna memelihara, membesarkan, dan mendidik yang di dalamnya sudah termasuk makna al-ta'lim. Sangkan ta'lim sendiri berasal dari kata 'allama', yang merujuk kepada Allah sebagai Zat Yang Maha Alim, maha mengetahui. Selanjutnya 'al-ta'dib' seperti termuat dalam pernyataan Rasulullah SAW. "addabani rabby fa ahsana ta'diby", yang menperjelas bahwa sumber utama pendidikan adalah Allah SWT. ${ }^{8}$

Dalam Alquran, ada sekiar $972^{9}$ kara " $r a b b$ ” dalam berbagai bentuknya, yang tersebar di hampir semua surah dalam Al-quran, yang pada umumnya berhubungan

\footnotetext{
${ }^{4}$ Ibn Munzhir, Lisan al-Araby (Dar al-Ma'rif, t.th.), h. 240.

${ }_{5}$ Abu Husayn Ahmad bin Faris bin Zakariyah, Mu'jam Maqayis al Lugah, Juz 6 (Dar al Fikri, t.th), h. 143.

${ }^{6}$ Atabik Aliy dan Ahmad Zuhdiy Muhdhor, Kamus Krafiyak al Aqnshary, Araby-Indonesia (vet. IV; Jakarta: Multi Karya Grafika, 1999), h. 2038-2039.

${ }^{7}$ Republik Indonesia, Undang-Undang No. 23 tahun 2002 tentang Perlindungan Anak

${ }^{8}$ H. Jalaluddin, Teologi pendidikan, (Cet. III; Jakarta: PT. Raja Grafindo Persada, 2003), h. 73.

${ }_{9}$ Muhmmad Fuad Abd. Baqy, Al-Mu'jamu al Mufahras li al-Fadzi al-Quran al-Karim, (Beirut: Dar al-Ma'arif, 1991), h. 362-379.
} 
dengan kata benda (isim), yang dapat diartikan sebagai pemelihara, pendidik, membesarkan. Berangkat dari pengertian ini, maka "tarbiyah" dapat didefinisikan sebagai proses bimbingan terhadap potensi manusia (jasmani, ruh, dan akal) secara maksimal agar dapat menjadi bekal dalam menghadapi kehidupan dan masa depan ${ }^{10}$. Quraish Shihab menggambarkan bahwa kata "rab" menggambarkan Tuhan dengan sifat-sifat-Nya (sifat-sifat fi'il-Nya). Dia Allah Rabbun dalam arti Dia mendidik, Dia memelihara, pendidikan dan pemeliharaannya itu antara lain; dengan menganugerahkan rezeki, mencurahkan rahmat, mengampuni dosa, namun sekaligus menyiksa dalam rangka pemeliharaan dan pendidikan-Nya ${ }^{11}$. Dalam bentuk kata benda, kata "rabba" ini digunakan juga untuk "Tuhan", mungkin karena Tuhan juga bersifat mendidik, mengasuh, memelihara, malah mencipta ${ }^{12}$.

Dengan demikian, maka kata "Rabb" bisa mengandung dua pengertian, bisa berarti Tuhan dan juga bisa diartikan sebagai pendidik, pemelihara, pengasuh. Namun kedua pengertian tersebut bisa dipadukan dengan menempatkan kata mendidik, mengasuh, memelihara, sebagai sifat Tuhan.

Selain kata " $r a b "$, kata yang sinomin dengan kata itu adalah kata "ta'lim". Zakiah Darajat mengatakan bahwa kata "ta'lim”, berarti pengajaran. Kata "ta'lim" dengan kata kerjanya "allama", juga sudah digunakan pada zaman Nabi. baik dalam Alquran, hadis, atau pemakaian sehari-hari. Dalam Alquran, kata ini diulangi sebanyak 4 kali, yakni pada surah al-Baqarah ayat 31, al-Rahman ayat 2, dan al-Alaq ayat 4 dan 5. ${ }^{13}$ Kata ini lebih banyak digunakan dari pada kata "tarbiyah" tadi. Dari segi bahasa, perbedaan arti kedua kata itu cukup jelas. Kata "allama" dalam Alquran surah alBaqarah: "Dan Dia mengajarkan kepada Adam nama-nama (benda-benda) sulurhnya..."14 menurut Qurash Shihab, ayat ini menginformasikan bahwa manusia dianugerahi oleh Allah SWT. potensi untuk mengetahui. Dia juga dianugerahi petensi untuk berbahasa. ${ }^{15}$ Pada kedua ayat tersebut, kata "allama" mengandung pengertian sekadar memberitahu atau memberi pengetahuan, tidak berarti pembinaan keperibadian. ${ }^{16}$ Ungkapan yang sama ditemukan dalam ayat 16 surah An Naml: "Dan Sulaiman telah mewarisi Daud dan dia berkata: "Hai manusia, kami telah diberi pengertian tentang suara burung dan kami diberi segala sesuatu. Sesungguhnya (semua) ini benar-banar suatu karunia yang nyata". ${ }^{17}$.

\footnotetext{
${ }^{10}$ H. Jalaluddin, Op. cit., h.72.

${ }^{11}$ Quraish Shihab, Mahkota Tuntunan Ilahi, (Jakarta: Untagama, t.th.) 21.

${ }^{12}$ Zakiah Darajat, Ilmu Pendidikan Islam, (Cet. Keenam; Jakarta: Bumi Aksara, 2006), h. 26.

${ }^{13}$ Muhammad Fuad Abdul Baqi, Op.cit., h. 603

${ }^{14}$ Departemen Agama RI., Op. cit., h. 14.

${ }^{15}$ Quraish Shihab, Tafsir al-Mishbah, Volume 1, (Cet. II; Jakarta: Lentera Hati, 2009), h. 176-177.

${ }^{16}$ Ibid., h. 27.

${ }^{17}$ Ibid., h.419.
} 
Oleh karena itu, kata "tarbiyah" lebih luas, karena di samping memberi pengajaran dan pengetahuan, juga membina keperibadian seseorang.

Selain kedua kata tersebut yang memiliki persamaan pengertian adalah kata "addaba" yang berarti memberi adab, mendidik. ${ }^{18}$ Kata ini didasarkan pada sabda Rasulullah SAW. :

Artinya: "Tuhanku telah mendidikku, maka ia sempurnakan pendidikanku"19.

Dengan demikian, maka baik al-tarbiyah, al Ta'lim maupun al-Ta'dib, merujuk kepada Allah. Tarbiyah yang merupakan bentukan dari kata "rabbun" atau "rabba", mengacu kepada Allah sebagai "Rabb al Aalamin". Sedangkan kata talim yang berasal dari kata "allama' juga merujuk kepada Allah sebagai Dzat yang Maha Alim. Selanjutnya " $t a$ 'dib" seperti termuat dalam hadis Rasulullah SAW.: "Addabany Rabby faahsana ta'diby" memperjelas bahwa sumber utama pendidikan adalah Allah SWT. ${ }^{20}$

Berdasarkan pengertian-pengertian tersebut di atas, maka pendidikan anak menurut Alquran adalah bimbingan, pemeliharaan, pembinaan, pengasuhan terhadap potensi yang dimiliki oleh anak, agar ia dapat tumbuh dan bekembang secara optimal untuk mencapai tujuan pendidikan yang sesuai dengan ajaran (konsep) Alquran.

Tujuan pendidikan yang dimaksud adalah tujuan akhir/ideal pendidikan Islam yang identik dengan tujuan penciptaan manusia, yakni terbentuknya manusia pengabdi (hambah Allah SWT.), seperti yang dinyatakan oleh Allah dalam Q.S. AdzDzariyaat/51: 56) yang terjemahnya: "Dan Aku tidak mencitakan jin dan manusia melainkan supaya mereka menyembahKu" 21

Qurash Shihab menjelaskan bahwa huruf "lam" pada kata "liya'budun” dalam ayat di atas, berarti kesudahan atau dampak dan akibat sesuatu. Ibadah bukan hanya sekadar ketaatan dan ketundukan, tetapi ia adalah satu bentuk ketundukan dan ketaatan yang mencapai puncaknya akibat adanya rasa kekaguman dalam jiwa seseorang terhadap siapa yang kepadanya ia mengabdi. ${ }^{22}$

\section{Metode Pendidikan Anak Menurut Alquran}

Alquran mengandung berbagai ajaran, termasuk tentang cara mendidik anak. Dalam Alquran, terdapat berbagai metode pendidikan yang baik diterapkan di dalam pendidikan anak.

${ }^{18}$ Mahmud Yunus, Kamus Arab-Indonesia, Jakarta: Yayasan Penterjemah/ Penafsir Al-Quran, 1973), h. 37.

\footnotetext{
19

${ }^{20}$ H. Jalaluddin, Op. cit., h. 73.

${ }^{21}$ Departemen Agama RI., Op. cit., h. 862

${ }^{22}$ Quraish Shihab, Volume 13, Op. cit., h. 108.
} 


\section{a. Metode Keteladanan}

Allah berfirman yang artinya: "sesungguhnya telah ada pada (diri) rasulullah itu suri teladan yang baik”. (Qs. 33/Al-Ahzab: 21).

Dalam menafsirkan ayat ini, az-Zamakhsyari dalam Quraish Shihab mengemukakan maksud keteladanan pada diri Rasulullah. Pertama dalam arti keperibadian beliau secara totalitas adalah teladan. Kedua dalam arti terdapat dalam keperibadian beliau hal-hal yang patut diteladani. ${ }^{23}$

Abdullah Nashih Ulwan( 1999: 142) menjelaskan, bahwa seorang anak, bagaimanapun besarnya usaha yang dipersiapkan untuk kebaikannya, bagaimanapun sucinya fitrah, ia tidak akan mampu memenuhi prinsip-prinsip kebaikan dan pokokpokok pendidikan yang utama, selama ia tidak melihat sang pendidik sebagai teladan dari nilai-nilai moral yang tinggi. ${ }^{24}$

Dalam proses perkembangan anak, terdapat suatu fase yang dikenal dengan fase imitasi. Pada fase ini, seorang anak selalu meniru dan mencontoh orang-orang dewasa di sekitarnya, terutama orang tuanya atau gurunya. Metode keteladanan ini sangat cocok diterapkan pada fase ini. Dalam pendidikan, pendidik (orang tua dan guru) tidak cukup hanya dengan memberi nasehat dalam arti menyuruh, tetapi seharusnya memberikan teladan. Misalnya; menyuruh anak ke masjid, sementara dia tidak pernah ke mesjid. Tidak satunya kata dan perbuatan, menjadikan orang tua/guru tidak memiliki wibawa sebagai pendidik, dan menjadikan anak bingung, karena apa yang dilihatnya tidak sesuai dengan apa yang didengarnya.

\section{b. Pendidikan dengan Pembiasaan}

Setiap anak yang lahir telah membawa fitrah/potensi yang suci. Sebagaimana firman Allah: " Fitrah Allah yang telah menciptakan manusia menurut fitrah itu. Tidak ada perubahan pada fitrah Allah. (Itulah) agama yang lurus, tetapi kebanyakan manusia tidak mengetahui" ${ }^{25}$ Potensi inilah yang akan dikembangkan dan dipelihara oleh lingkungannya melalui pembiasaan.

Tidak ada yang menyangkal, bahwa anak akan tumbuh dengan iman yang benar, berhiaskan diri dengan etika islami, bahkan sampai pada puncak nilai-nilai spritual yang tinggi, dan keperibadian utama, jika ia hidup dan dibekali dengan dua faktor yaitu pendidikan islami yang utama dan lingkungan yang baik. ${ }^{26}$

Sesuatu yang dibiasakan sejak kecil, akhirnya akan menjadi keperibadian seseorang. Hal itu akan nampak dalam tingkah laku, tutur katanya, cara berpikirnya, bahkan dalam falsafah hidupnya.

\footnotetext{
${ }^{23}$ Ibid., Volume 10, h. 439.

${ }^{24}$ Abdullah Nashih Ulwan, Pendidikan Anak Dalam Islam, Jil. II, (Cet. II; Jakarta: 1999), h.142.

${ }^{25}$ Departemen Agama, Op. cit., h. 645.

${ }^{26}$ Abdullah Nashih Ulwan, Op. cit., h.185-186.
} 


\section{c. Pendidikan dengan Nasehat}

Pemberian nasehat merupakan salah satu metode pendidikan yang dianggap cukup berpengaruh terhadap seorang anak. Hal ini telah dilaksanakan oleh Lukmanul Hakim dalam mendidik anak-anaknya melalui nasehat-nashat. Berulang kali Lukman menasehati anak-anaknya yang dinyatakan dalam Alquran surah Lukman pada ayat 11 s.d. 19 , yang intinya sebagai berikut:

1. Jangan mensyerikatkan Allah karena mensyerikatkan Allah benar-benar kedzaliman yang besar.

2. Allah menasehati agar selalu berbuat baik kepada kedua orang tua dan bersyukurlah kepada Allah dan kepada kedua ibu bapak.

3. Jika kedua orang tua mengajak untuk mempersekutukan Allah, maka janganlah mengikuti keduanya, tetapi tetap perlakukan keduanya dengan baik.

4. Bahwa semua perbuatan itu akan dibalas oleh Allah SWT., sekalipun disembunyikan dengan baik

5. Dirikanlah salat dan suruhlan manusia berbuat baik dan cegahlah mereka dari perbuatan mungkar.

6. Bersabarlah terhadap segala yang menimpa kamu, sesungguhnya yang demikian termasuk yang diwajibkan oleh Allah.

7. Jangan memalingkan diri dari manusia karena perasaan sombong dan janganlah berjalan di muka bumi dengan sombong, karena allah tidak menyukai orang-orang sombong lagi membanggakan diri.

8. Sederhanalah dalam berjalan dan lunakkanlah suaramu, sesungguhnya seburukburuk suara adalah suara keledai. ${ }^{27}$

Apa yang disampaikan Luqman kepada anak-anaknya yang terangkum dalam kalimat-kalimat di atas, semuanya merupakan nasehat buat anak-anaknya dan juga buat generasi di belakangnya, dan merupakan salah satu metode pendidikan.

Selain apa yang dicontohkah oleh Allah SWT. dalam surah Luqman di atas, tentang pemberian nasehat banyak dikemukakan oleh Allah SWT. seperti antara lain: Qs. 35/Saba': 46-49, Qs. 11/Hud: 32-34, Qs. 7/al-A'raf: 65-68, Qs. 50/Qaf: 8 dan 37 , Qs. Adz-Dzariyat: 55, Qs. 11/Hud: 114, dan Qs. 65/ath-Thalaq: 2.

Dengan demikian, betapa banyak ayat Alquran yang menunjukkan betapa pentingnya nasehat itu dalam pelaksanaan pendidikan. Para pendidik hendaknya memahami dan menggunakan metode-metode Alquran dalam upaya pemberian nasehat, peringatan dan bimbingan untuk mempersiapkan anak-anak dalam hal akidah maupun moral, dalam pembentukan keperibadian maupun kehidupan sosial jika memang mereka menginginkan kebaikan, kesempurnaan dan kematangan akhlak dan akal anak-anak. ${ }^{28}$

${ }^{27}$ Disadur dari Departemen Agama RI., Op. cit., h. 654-655

28 Abdullah Nashih Ulwan, Op. cit., h. 215. Bandingkan dengan Heri Jauhari Muchtar, Fikih Pendidikan, (Bandung: Remaja Rosda Karya, 2008), h. 215-230. 


\section{d. Pendidikan dengan Pengawasan/Perhatian}

Dalam Alquran Allah SWT. berfirman yang terjemahnya sebagai berikut:

"Hai orang-orang yang beriman, peliharalah dirimu dan keluargamu dari api neraka yang bahan bakarnya adalah manusia dan batu, penjaganya malikat-malaikat yang kasar, keras, yang tidak mendurhakai Allah terhadap apa yang diperintahkan-Nya kepada Mareka dan selalu mengerjakan apa yang diperintahkan." (Qs.66/ At-Tahrim: $6)^{29}$

Ayat tersebut menggambarkan bahwa pemberian perhatian pada anak dalam fase perkembangannya merupakan salah satu metode pendidikan menurut Alquran. Nasib akan sangat ditentukan oleh perhatian yang diberikan oleh orang tuanya/pendidiknya. Perhatian merupakan salah satu kebutuhan psikis yang sangat dibutuhkan oleh seorang anak dalam masa perkembangannya. Kurangnya perhatian dan pengawasan yang diberikan oleh orang tua, akan membuat seorang anak menjadi liar dari lingkungannya. Perhatian ini tidak dapat diukur dan diganti dengan pemberian materi, sebab materi merupakan kebutuhan jasmaniah, sedang perhatian merupakan kebutuhan rohaniah.

Quraish Shihab dalam menafsirkan ayat ini mengatakan bahwa ungkapan: Hai orang-orang beriman peliharalah diri kamu antara lain dengan meneladani Nabi, dan pelihara juga keluarga kamu, yakni isteri, anak-anak, dan seluruh yang berada di bawah tanggung jawab kamu, dengan membimbing dan mendidik mereka, agar kamu semua terhindar dari api neraka. Selanjutnya dikatakan pada ayat enam di atas menggambarkan bahwa pendidikan harus dimulai dari rumah, dan ditujukan kepada ayah dan ibu. ${ }^{30}$

Ibu bapak merupakan orang yang paling bertanggung jawab terhadap pendidikan anak-anak, terutama ketika anak masih berada pada fase perkembangan di mana mereka sangat membutuhkan perhatian dan bimbingan, yakni pada masa anak dan masa pubertas, karena pada masa ini, seorang anak akan mengalami masa kegoncangan kejiwaan. Pada fase ini, seorang anak sangat membutuhkan bimbingan dan perhatian dari orang-orang dewasa disekitarnya, terutama orang tuanya. Abdullah Nashih Ulwan mengatakan, bahwa memperhatikan dan mengawasi anak yang dilakukan oleh pendidik, adalah asas pendidikan yang paling utama. Mengingat anak akan selalu dibawah perhatian dan pengawasan pendidikan jika pendidik selalui memperhatikan segala gerak gerik, ucapan dan perbuatan, sehingga jika mereka melalaikan kewajiban, segera diluruskan, jika melihat sesuatu yang mungkar, dicegah agar tidak mendekatinya. Jika mereka berbuat ma'ruf, ucapkan terima kasih dan bersyukurlah, serta beri motivasi agar senantiasa melakukan perbuatan baik itu. ${ }^{31}$

\footnotetext{
${ }^{29}$ Departemen Agama, Op. cit., h. 951

${ }^{30}$ Quraish Shihab, Volume 14, Op. cit., h. 177.

${ }^{31}$ Abdullah Nshih Ulwan, Op. cit., h. 278.
} 
Dengan perhatian yang senantiasa diberikan kepada anak, anak akan selalu merasakan betapa orang tua/gurunya menyayanginya, sehingga jika anak melakukan perbuatan yang baik, sang anak akan mendapatkan hadiah, walaupun hanya dengan mimik. Demikian pula jika ia melakukan suatu kesalahan, ia akan memperoleh hukuman, sekalipun hanya dengan mimik saja. Hal ini akan sangat berpengaruh dalam kehidupan anak. Perhatian yang diberikan merupakan kebutuhan rohaniah yang tidak bisa digantikan dengan materi, sebab materi adalah kebutuhan jasmaniah, dan tidak dapat ditukar satu dengan yang lain. Dengan demikian, maka perhatian merupakan salah satu metode pendidikan dalam Islam.

\section{Isi Pendidikan Anak Menurut Alquran}

Isi pendidikan menurut Alquran, adalah apa yang menjadi materi pendidikan yang diberikan kepada anak, sejak awal, sehingga fitrah/potensi yang dibawanya tetap terpelihara dalam sepanjang kehidupannya, tidak dikotori dengan hal-hal yang yang merusakkan fitrah/potensi itu.

Kalau kita perhatikan contoh-contoh pendidikan yang disebutkan dalam Alquran, dengan jelas dapat diketahui isi dari pendidikan menurut Alquran, yaitu:

\section{a. Pendidikan Akidah}

Sejak anak lahir, anak sudah berbekal berbagai potensi, di antaranya adalah potensi imaniah, seperti yang dijelaskan oleh Allah dalam Alquran surah al-A'raf ayat 172 sebagai berikut:

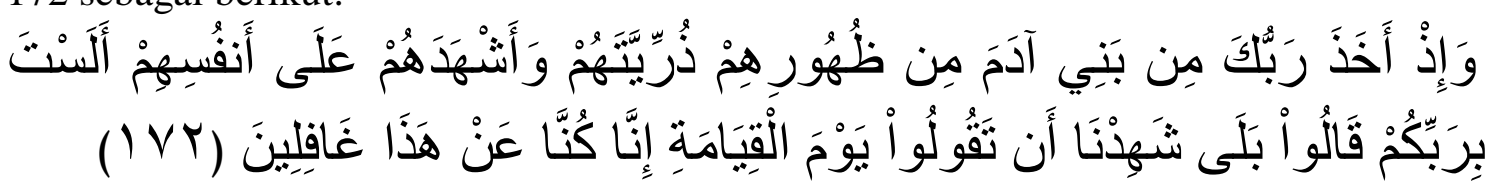

Terjemahnya:

Dan (ingatlah), ketika Tuhanmu mengeluarkan keturunan anak-anak Adam dari sulbi mereka dan Allah mengambil kesaksian terhadap jiwa mereka (seraya berfirman): “Bukankah Aku ini Tuhanmu ?” mereka menjawan : "Betul (Engkau Tuhan kami), kami menjadi saksi, (Kami lakukan yang demikian itu) agar di hari kiamat kamu tidak mengatakan: "sesungguhnya kami (bani Adam) adalah orang-orang yang lengah terhadap ini (keesaan Allah) ${ }^{32}$. (Qs. 7/al-A'raf: 172).

Quraish Shihab dalam menafsirkan asyat mengakatan Dia, yakni Allah mempersaksikan mereka putra-putra Adam itu atas diri mereka sendiri, yakni meminta pengakuan mereka masing-masing melalui potensi yang dianugrahkan Allah kepada mereka, juga melalui penghamparan bukti keesaanNya di alam raya dan pengutusan para nabi seraya berfirman: "Bukankah Aku pemeliharaa kamu dan yang selalu berbuat

\footnotetext{
${ }^{32}$ Departemen Agama RI., Op. cit., h. 250
} 
baik kepada kamu?" Mereka menjawab: "betul kami menyaksikan bahwa Engkau adalah Tuhan kami dan menyaksikan pula bahwa Engkau Maha Esa. ${ }^{33}$

Jika pendidikan anak jauh dari akidah Islam, lepas dari ajaran religius dan tidak berhubungan dengan Allah, maka tidak diragukan lagi bahwa anak akan tumbuh dewasa di atas kefasikan, penyimpangan, kesesatan, dan kekafiran. Bahkan ia akan mengikuti nafsu dan bisikan-bisikan setan, sesuai dengan tabiat, fisik, keinginan dan tuntutasnnya yang rendah. ${ }^{34}$

Ayat di atas menunjukkan bahwa sebelum manusia lahir ke dunia, manusia (jiwa) telah mengadakan perjanjian suci dengan Allah berupa pentauhidan Allah . Pentauhidan ini dibawah oleh manusia lahir ke dunia yang disebut dengan potensi imaniah (fitrah beragama). Potensi ini merupakan kemampuan yang masih terpendam (laten). Untuk mengaktualisasikannya memerlukan bantuan, dan bantuan itulah yang disebut dengan pendidikan. Pendidikan itu sifatnya memelihara dan menumbuhkambangkan potensi yang dibawah oleh manusia sejak lahir.

\section{b. Pendidikan Akhlak}

Pendidikan yang kedua yang contohkan oleh Luqman al-Hakim adalah pendidikan akhlak. Seperti yang dinyatakan dalam Alquran ketika Luqman menasehati anaknya dan berkata :

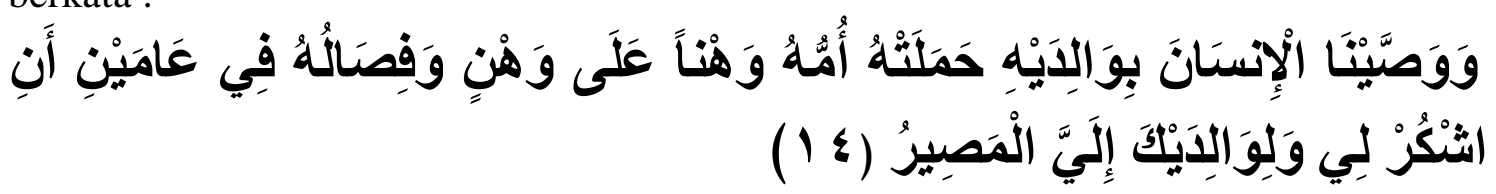

Terjemahnya:

"Dan Kami perintahkan kepada manusia (berbuat baik) kepada dua orang ibu bapaknya yang telah mengandungnya dalam keadaan lemah yang bertambah-tambah dan menyepihnya dalam dua tahun. Bersyukurlah kepadaKu dan kepada dua orang ibu bapakmu, hanya kepada-Kulah kembalimu"35

Dalam ayat ini, ada dua macam pendidikan akhlak, yaitu akhlak kepada kedua ibu bapak, akhlak yang berhubungan dengan besyukur kepada Allah dan kepada kedua ibu bapak, dan berbuat baik kepada keduanya, sekalipun keduanya mengajak kita untuk mensyerikakan Allah. Selain itu, pada ayat berikutnya dinyatakan bahwa setiap perbuatan itu pasti ada balasannya, sehinggga dalam melakukan suatu perbuatan perlu dipikirkan kebaikan dan kebutukannya, sehingga dalam melakukan pekerjan, perlu berhati-hati atau teliti. Pada ayat selanjutnya (18 dan 19), juga mengandung ajaran akhlak yang mulia. Di kedua ayat itu, dinyatakan bahwa:

"jangan kamu memalingkan mukamu dari manusia (karena sombong) dan jangan berjalan di muka bumi dengan angku, karena sesungguhnya Allah tidak menyukai

\footnotetext{
${ }^{33}$ Quraish Shihab, Volume 4, Op. cit., h. 369.

${ }^{34}$ Abdullah Nashih Ulwan, Jil. I, Op. cit., h. 194

${ }^{35}$ Departemen Agama RI., Op. cit., h. 654.
} 
orang-orang yang sombong lagi angkuh. Dan sederhanalah kamu dalam berjalan, dan lunakkan suaramu, sesungguhnya seburuk-buruk uara adalah suara keledai",36

Rasulullah bersabda yang artinya:

"Ajarkanlah kebaikan kepada anak-anakmu dan didiklah mereka dengan budi pekerti yang baik" (HR. Abdurrazak dan Said bin Manshur dan selainnya kedduanya).

Selanjutnya Rasulullah mengatakan:

"Di antara yang menjadi hak seorang anak terhadap orang tuanya adalah memperolek budi pekertinya dan menamakannya dengan nama yang baik” (HR. Al Baihaqy) ${ }^{37}$

\section{c. Pendidikan Ibadah}

Salah satu bentuk pendidikan yang dinasehatkan Luqman kepada anak-anaknya adalah pelaksanaan ibadah (shalat), seperti dinyatakan:

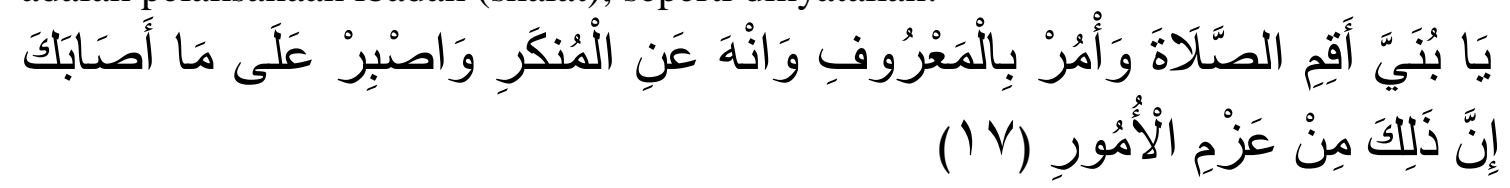

Terjemahnya:

Hai anakku, dirikanlah shalat dan seruhlah (manusia) mengerjakan yang baik $d n$ cegahlah (mereka) dari perbuatan yang mungkar dan bersabarlah terhadap apa yang menimpa kamu. Sesungguhnya yang demikian itu termasuk hal-hal yang diwajibkan (oleh Allah). (Qs. 31/Luqman: 17)

Nasihat Luqman diatas, menyangkut hal-hal yang berkaitan dengan amal saleh yang puncaknya adalah shalat serta amal-amal kebajikan yang tercerrmin dalam amar ma'ruf dan nahi mungkar juga nasihat berupa perisai yang membentengi seseorang dari kegagalah yang sabar dan tabah. ${ }^{39}$

Dari sini dapat dipahami bahwa pendidikan ibadah (shalat), tidak berdiri sendiri, melainkan harus bergandengan dengan amal-amal yang lain, seperti amar ma'ruf dan nahi mungkar. Dan juga berisi pendidikan kesabaran, karena di dalam beramar mas'ruf dan bernahyi mungkar, pasti akan menemui berbagai hambatan dan tantangan.

\section{d. Pendidikan Fisik}

Pendidikan fisik merupakan tnggung jawab pendidik, terutama orang tua, agar anak tumbuh dengan fisik yang kuat, bergairah dan bersemangat. Allah berfirman:

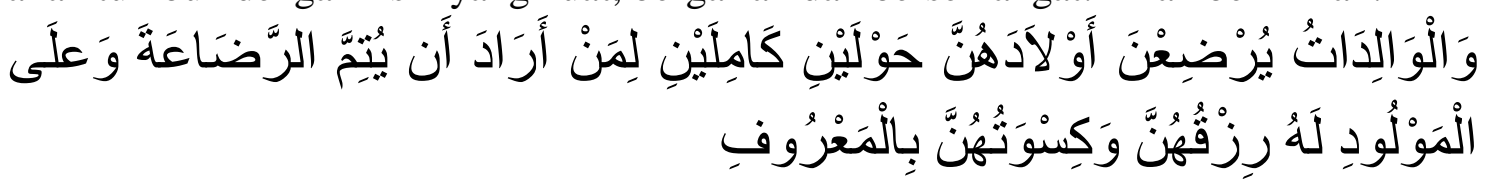

\footnotetext{
${ }^{36}$ Ibid., h. 655.

${ }^{37}$ Abdullah Nashih Ulwan, Op. cit., h. 198.

${ }^{38}$ Departemen Agama RI, Op. cit., h.665

${ }^{39}$ Quraish Shihab, Op. cit., h. 309.
} 
Terjemahnya:

Dan kewajiban ayah adalah memberi makan dan pakaian kepada para ibu dengan cara yang makruf. ${ }^{40}$

Dalam ayat ini disinggung tentang penyusuan. Penyusuan itu dianggap sempurna oleh Allah apabila dicukupkan dua tahun lamanya. Dari segi kesehatan, air susu ibu (ASI) mengandung berbagai zat yang sangat dibuthkan anak pada masa vital. Menurut penelitian kedokteran, zat yang terkandung dalam ASI itu sangat lengkap untuk pertumbuhan anak dan tidak produk susu yang dapat menandinginya. Hal ini menunjukkan betapa Alquran mementingkan pendidikan dan pertumbuhan jasmani seorang anak.

\section{e. Pendidikan Rasio}

Ayat yang pertama turun, memberikan petunjuk betapa pentingnya pengetahuan. Perintah membaca merupakan suatu bentuk pendidikan rasio, karena membaca merupakan pintu gerbang masuk ilmu pengetahuan, dan di sini yang berperan penting adalah rasio manusia. Allah berfirman:

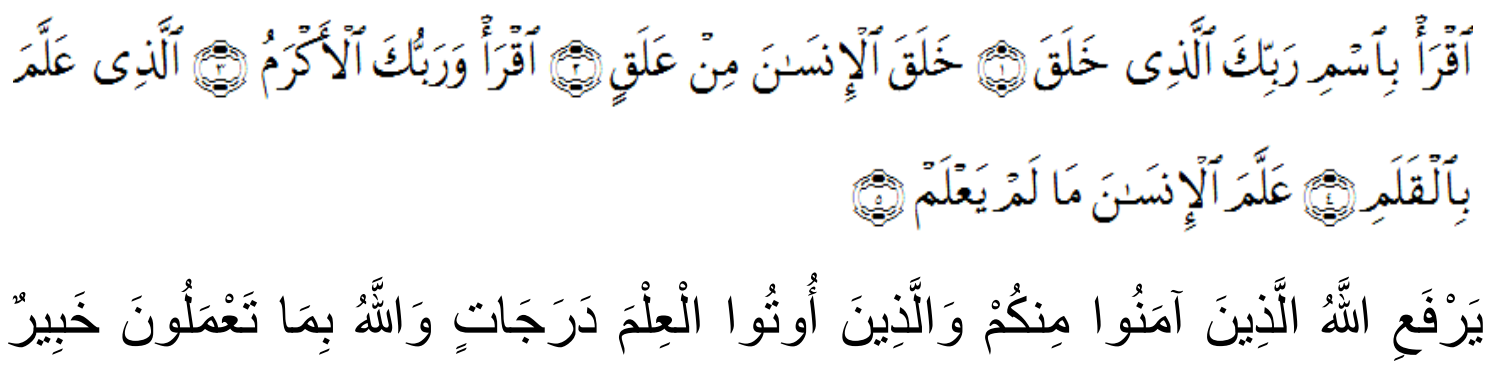

Ayat-ayat di atas, dan banyak lagi ayat lain menunjukkan betapa Alquran mementingkan pengembangan rasio sebagai alat untuk memperoleh dan mengembangkan ilmu pengetahuan dan teknologi.

\section{f. Pendidikan Sosial}

Islam sangat menganjurkan persaudaraan di antara sesama manusia, tanpa memandang suku, agama, ras. Allah berfirman dalam Qs. Al Hujurat:

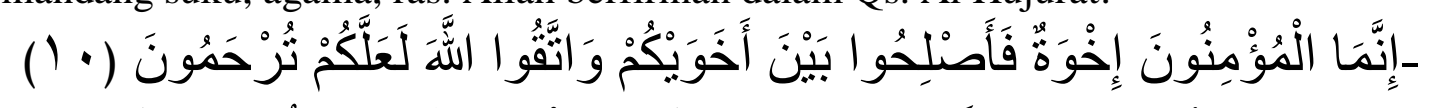

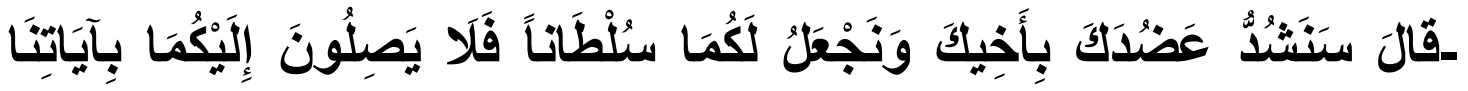

\footnotetext{
${ }^{40}$ Departemen Agama, Op. cit., h. 57.
} 


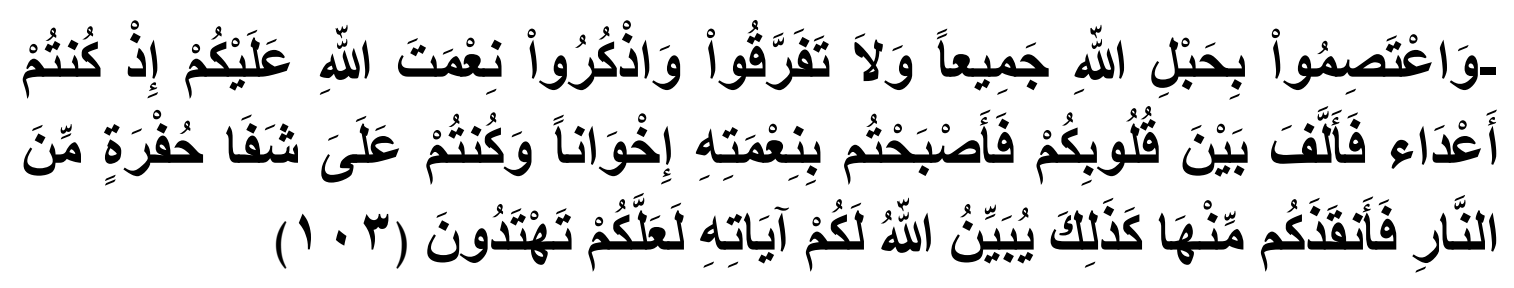

Ayat-ayat di atas, menggambarkan betapa Alquran menganjurkan persaudaraan, kedamaian sosial. Hal ini harus ditanamkan kepada anak sejak dini, sehingga mereka tidak terjangkiti perasaan egois ketika mereka sudah di masyarakat.

Dalam menafsirkan ayat 103 surah Ali Imran di atas, Quraish Shihab mengatakan, kata wala tafarraqu/janganlah bercerai berai, pesan yang dimaksud adalah: berpegng teguhlah, yakni upayakan sekuat tenaga untuk mengaitkan diri satu dengan yang lain dengan tuntunan Allah sambil menegakkan disiplin kamu semua tanpa kecuali, sehingga kalau ada yang lupa diingatkan dia, atau yang tergelincir bantu dia bangkit agar semua dapat bergantung pada tali agama Allah. ${ }^{41}$

Jadi persaudaraan merupakan bagian yang sangat penting dalam kehidupan sosial, bukan saja persaudaraan karena ikatan keturunan, tetapi yang lebih utama adalah persaudaraan bathin/kejiwaan. Persaudaraan ini biasanya lebih kuat dibandingkan dengan persudaraan karena kaurunan.

\section{PENUTUP}

\section{A. Kesimpulan}

Berdasarkan uraian-uraian di atas, dapat ditarik beberapa kesimpulan sebagai berikut:

a. Anak yang dimaksud dalam uraian makalah ini, tidak dibatasi dengan UU Nomor 23 tahun 2003 tentang perlindungan anak, tetapi lebih mengarah pada anak yang masih dalam pengawasan dan tanggung jawab orang tua.

b. Pendidikan anak dimaksudkan adalah bimbingan, pemeliharaan, pengasuhan terhadap potensi yang dimiliki oleh anak agar dia dapat tumbuh secara optimal untuk mencapai tujuan pendidikan sesuai dengan ajaran Islam (Alquran).

c. Metode pendidikan menurut Alquran adalah keteladanan, pembiasaan, nasehat, dan pengawasan.

d. Isi atau meteri pendidikan menurut Alquran meliputi, pendidikan aqidah, akhlak, ibadah, pendidikan fisik, pendidikan rasio, pendidikan, dan pendidikan sosial.

\section{B. Implikasi}

a. Bahwa pendidikan pada masa anak, adalah pendidikan yang sangat vital, merupakan pendidikan yang pertama dan utama, sehingga masa anak perlu mendapatkan perhatian yang sungguh-sungguh, baik dari orang tua, sekolah, maupun masyarakat.

\footnotetext{
${ }^{41}$ Qurash Shihab, Volume 2, Op. cit. h. 205.
} 
b. Pendidikan menurut Alquran tidak terbatas pada pendidikan aqidah, akhlak atau ibadah, tetapi meliputi lingkup pendidikan yang luas, sehingga dalam pelaksanaan pendidikan pada lembaga pendidikan Islam, tidak hanya bercirikan ketiga isi pendidikan tersebut.

\section{DAFTAR PUSTAKA}

Abd. Baqy, Muhammad Fuad. Al Mu'jam al Mufahrasli al-Fadzi al-Quran al-Karim. Beirut: Dar al- Ma'arif, 1991.

Abu Husayn Ahmad bin Faris bin Zakariyah. Mu'jam Maqayis al Lugah. Juz 6. Dar al Fikri, t.th.

Arifin, Muzayyin. Filsafat Pendidikan Islam. Jakarta: PT. Bumi Karsa, 2008.

Atabik Aliy dan ahmad Zuhdiy Muhdhor, Kamus Krafiyak al Aqnshary, ArabyIndonesia (vet. IV; Jakarta: Multi Karya Grafika, 1999), h. 2038-2039.

Darajat, Zakiah. Ilmu Pendidikan Islam. Cet. VI; Jakarta: Bumi Aksara, 2006

Departemen Agama RI. Al Qur'an dan Terjemahnya. (Saudi Arabiah: Mujamma' alMalik Fahd li Tiba'at Mush-haf Asy-Syarif Medinah Munawwarah, t.th.

Heri Jauhari Muchtar. Fikih Pendidikan. Bandung : Remaja Rosda Karya, 2008.

Ibn Munzhir. Lisan al-Araby. Dar al-Ma'rif, t.th.

Ibnu Rusn, Abidin. Pemikiran al-Gazali tentang Pendidikan. Cet. II; Yogyakarta: Pustaka Pelajar. 2009.

Jalaluddin. Teologi Pendidikan. Cet. III; Jakarta: PT. Raja Grapindo Persada, 2003.

Langgulung, Hasan. Asas-Asas Pendidikan Islam. Cet. V; Jakarta: PT. Pustaka Al Husna baru, 2003.

Langgulung, Hasan. Manusia dan Pendidikan Suatu analisa Psikologi dan Pendidikan. Cet. III; Jakarta: PT. Al Husna Zikra, 1995.

Mahmud. Pemikiran Pendidikan Islam. Bandung: Sahifa, 2005.

Nashih Ulwan, Abdullah. Tarbiyah al-Aulad fi al-Islam. Diterjemahkan oleh Jamaluddin Miri dengan judul: "Pendidikan Anak Dalam Islam". Cet. III; Jakarta: Pustaka Amani, 2007.

Republik Indonesia. Undang-Undang Nomor 23 tahun 2003 tentang Perlindungan Anak.

Shihab, Quraish. Mahkota Tuntnan Ilahi Pesona Al Fatihah. Jakarta: Untagama, t.th. 
Shihab, Quraisy. Tafsir Al Misbah. Volume 1, 2, 4, 10, 13, 14, Cet. II; Jakarta: Lentera Hati, 2009.

Zuhairini dkk. Filsafat Pendidikan Islam. Cet. IV. Jakarta: Bumi Aksara, 2008. 